\title{
THE INFLUENCE OF THE RS7566605 IN OVERWEIGHT IN DIFFERENT POPULATIONS - A SYSTEMATIC REVIEW
}

\author{
Caíque Almeida Costa*, Caroline Feitosa**, Geraldo Ferraro*** \\ Corresponding author: Geraldo Ferraro - geraldoferraro@bahiana.edu.br \\ * Biomedicine undergraduation student in BAHIANA - School of Medicine and Public Health \\ ** Phd Student in Public Health in the Federal University of Bahia, professor at BAHIANA - School of Medicine and Public \\ Health \\ *** Professor at the BAHIANA - School of Medicine and Public Health
}

\begin{abstract}
Introduction: Obesity and overweight are major worldwide public health problems associated with several etiological factors. The 157566605 polymorphism in the INSIG-2 gene is reported to be associated with the development of obesity. This polymorphism occurs when there is a change in the nitrogenous base guanine $(G)$ for cytosine $(C)$ resulting in two possible mutant genotypes: CC and CG. The wild genotype is represented by GG. Many authors reported the association between this polymorphism with anthropometrical changes, but there is no consensus regarding this issue. Objective: to evaluate the frequency of rs7566605 polymorphism and its association with obesity markers in populations from different geographical areas. Method: systematic review using PubMed and following the PRISMA Guidelines. Results: there was a great variability in terms of sample size, areas, bias and phenotypic characteristics. Although 38 biological traits were evaluated, the mutation was associated with only three of them (BMI, Waist-Hip Ratio, $\mathrm{HbAlc}$ ). The highest CC frequency was found among obese Malays $(21 \%)$, and the lowest among overweight Quilombo people (3\%). The highest CG frequency was found in non-obese Malays (51\%), while the lowest was reported among overweight Quilombo people (22\%). Also, Quilombo people reported the highest frequency of the GG phenotype (75\%), while the lowest frequency was found in non-obese Malays (32\%). Conclusion: The polymorphism was associated with only three obesity markers. There were specific patterns of genotypic frequency among populations belonging to similar geographical areas and/or ancestry. More research into the genetic factors related to obesity markers is needed.
\end{abstract}

Kepwords: INSIG-2; rs7566605; Obesity. 


\section{INTRODUCTION}

According to the World Health Organization (WHO) obesity and overweight are defined as an abnormal or excessive fat accumulation ${ }^{(1)}$ which are associated with the development of several diseases such as diabetes, hypertension, congestive heart failure, cardiovascular and coronary heart disease. (2-5) In 2014, more than 1.9 billion of adults over the age of 18 were classified as overweighted, and more than 600 million of those were obese. ${ }^{(1)}$ Its prevalence has been increasing over the years, ${ }^{(1,6,7)}$ and it is defined as a multifactorial phenomenon related to genetic and environmental factors. ${ }^{(8,9)}$

Many genes are reported to be related to the development of obesity in human populations..$^{(10-14)}$ Among those, the $\mathrm{r} 57566605$ polymorphism in the insulin-induced gene 2 (INSIG-2) is described as a potential etiological factor. ${ }^{(11)}$ This polymorphism occurs when there is a change in the nitrogenous base guanine $(G)$ for cytosine (C), which is located $10 \mathrm{~Kb}$ upstream of INSIG-2, resulting in two possible genotypes: CC mutant homozygous and CG heterozygous. The wild genotype is represented by GG. ${ }^{(15)}$ At high sterol concentrations the insig-2 protein inhibits the production of triglycerides, phospholipid, cholesterol and unsaturated fatty acid. ${ }^{(16,17)}$ It is speculated that the $\mathrm{rs} 7566605$ can impact this process, but it is still unclear. ${ }^{(11)}$
Despite the fact that several previous studies have reported an association between the rs7566605 polymorphism and anthropometric changes, ${ }^{(11,14,18-21)}$ others have shown no association at all. ${ }^{18,23,24-32)}$ The controversial results of these works call for a systematic review for a better understanding of the role of this polymorphism in obesity. Furthermore, there is a scarcity of literature review on this subject. The aim of this study is to systematically review the literature on the distribution of $\mathrm{rs} 7566605$ polymorphism in different populations from several geographic areas and its relationship with obesity.

\section{METHODS}

This systematic review was prepared following the PRISMA Guidelines. ${ }^{(33)}$ A survey of full text papers in English on the electronic database Pubmed was carried out using the following algorithm Search "obesity AND (INSIG-2 OR rs7566605) Filters: Publication date from 2010/12/18 to 2014/12/18". The keywords were INSIG-2, rs7566605, and obesity. The identification and inclusion of papers was performed by two reviewers, and there was no disagreement (figure 1).

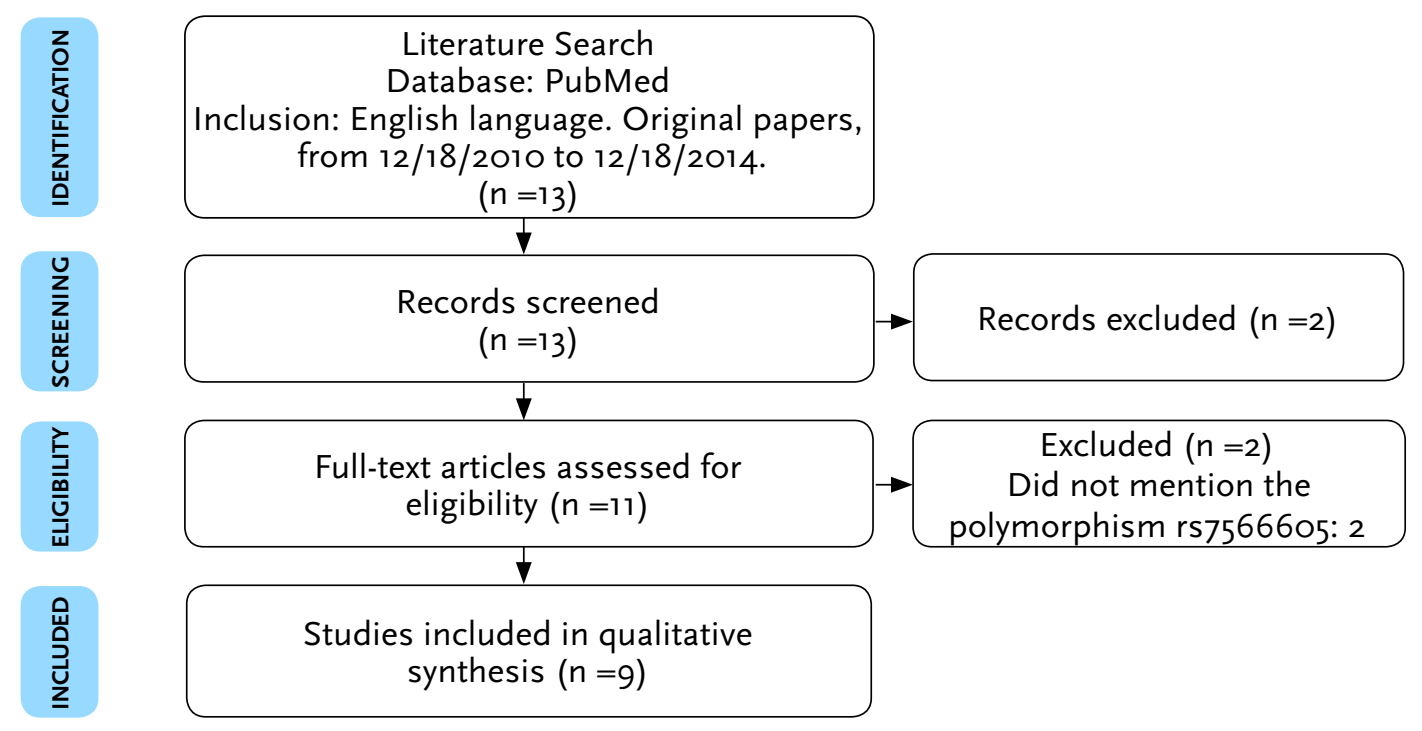

Figure 1 - PRISMA Flow Diagram 
Eligibility criteria: For this review, we included papers that presented the following characteristics: (1) Original articles, (2) with human participants of any age group, any gender and from different countries, (3) with assessment of the genotype frequencies and phenotype variables related to obesity.
Data items: Information was collected from all papers such as: (1) Characteristics of participants (age, ethnicity, genotype frequencies for $\mathrm{rs7566605}$ polymorphism); (2) Characteristics of the study (study type, follow-up time for the cohort studies, number of participants); (3) Associated variables (figure 2).

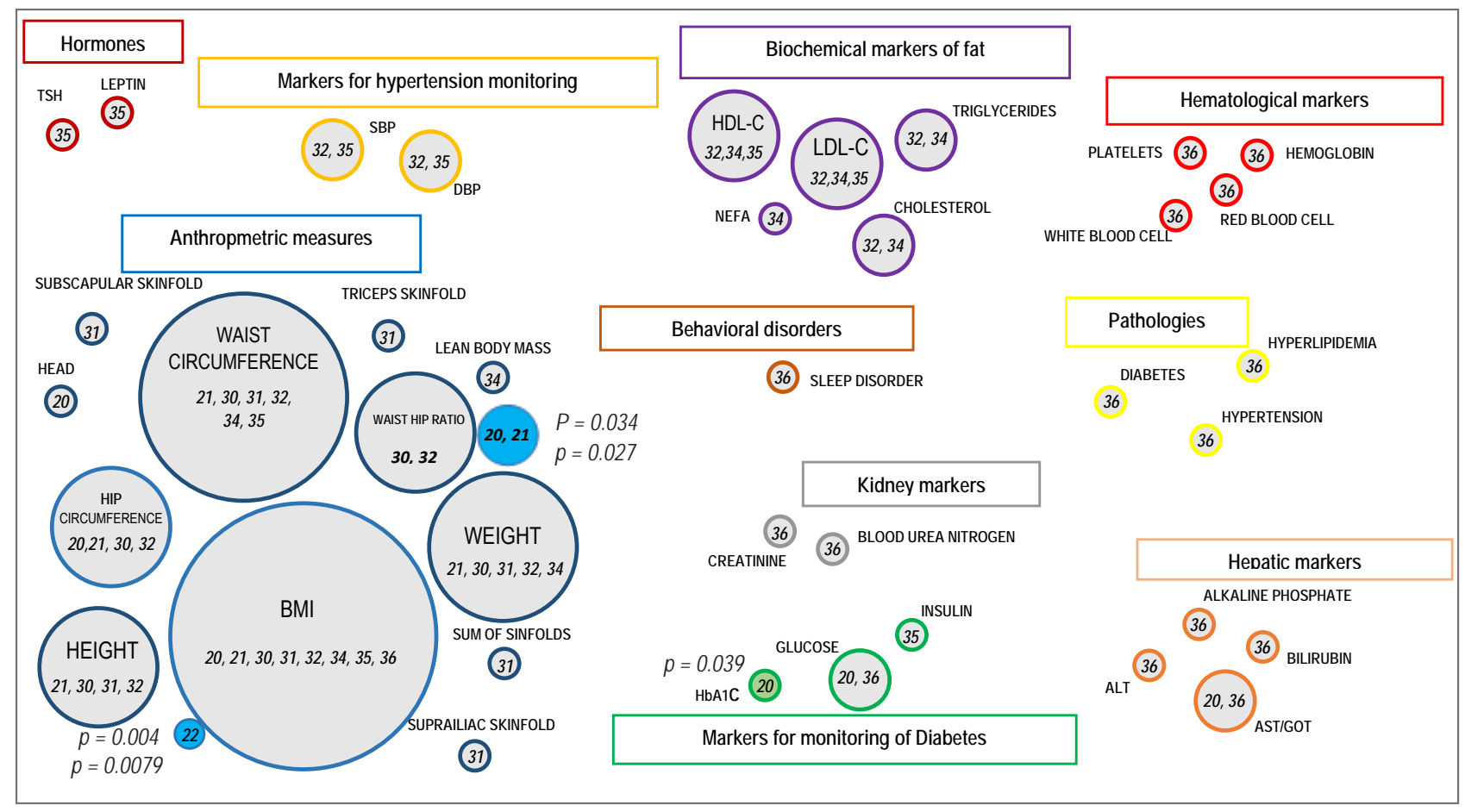

Figure 2 - Phenotypic characteristics related to obesity

Phenotypic characteristics related to obesity are organized in circles with proportional sizes, according to the amount of citations. Circles filled with gray color represent the characteristic studied with no significative association in the studies. Circles colored inside, represent characteristics associated. Digits inside the circle are the reference number. P-values are reported along with the colored circles. BMI- Body mass index. TSH- Thyroid-stimulating hormone. SBP- Systolic blood pressure. DBP- Diastolic blood pressure. NEFA- Non-esterified fatty acids, HDL-C- High-density lipoprotein cholesterol. LDL-C- Low-density lipoprotein cholesterol. ALT- Alanine aminotransferase. AST- Aspartate aminotransferase. GOT- glutamic oxaloacetic transaminase. HbAlc- hemoglobin Alc. Adapted. ${ }^{(43)}$

Summary measures: There was a lack of agreement between the measures of association reported among the different studies. The p-value was the main measure to assess the association between the studied mutation and the variables related to obesity, because it was reported in all the selected studies.
Additional analyses: For the papers which did not report the genotypes, the frequency was calculated using the crude data from the result section provided by the papers. These frequencies are presented in graph 1. 


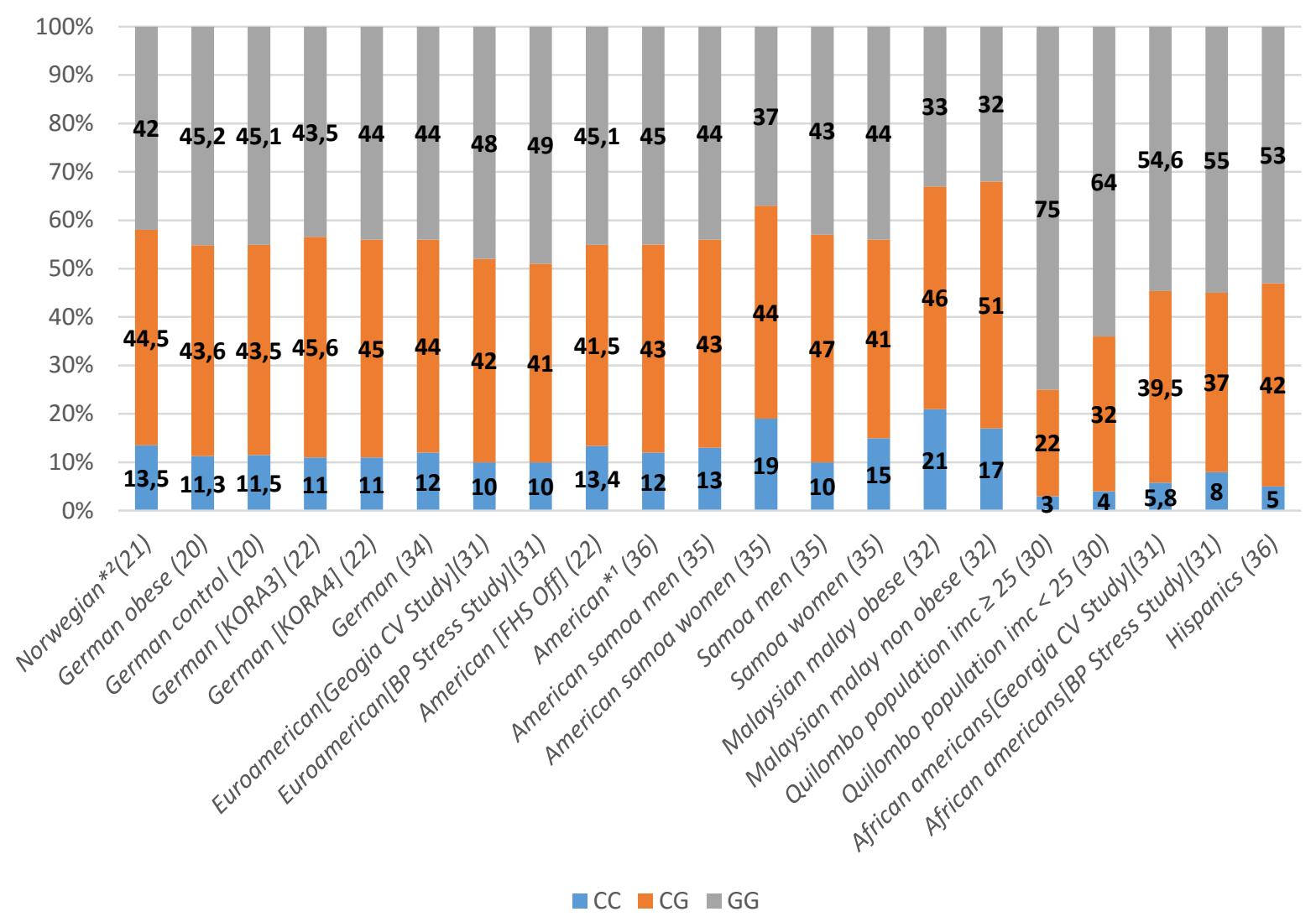

Graph 1 - Genotypic frequencies of the rs75666605 among different populations

Numbers inside collums represent the percentage of the genotypes. CC-Mutant Homozygous, CG- Wild Heterozygous, GG- Wild Homozygous; Numbers inside the parentheses (n) represent the reference number. Groups of study are inside square brackets [ ]. For some papers, the genotype percentage was calculated by the authors*.Genotypic frequency provided by the autor via e-mail.*.Ethnicity provided by the autor via e-mail.

\section{RESULTS}

After reviewing and applying the inclusion and exclusion criteria, 13 papers were screened and 9 papers were selected. From the 13 papers, 2 were excluded because the title did not contain the keywords and other 2 papers because they did not investigate the rs7566605 polymorphism, leaving 9 papers for complete analysis (figure 1).

The selected studies used different study designs, including case-control, cross-sectional and cohort studies. The studies included 16,617 obese and nonobese participants with a BMI (Body Mass Index) ranging from $19.9 \pm 4.8$ to $50.2 \pm 8.8$, from different geographical areas (graph 1), with ages from birth to 74 years old (table 1). The follow-up time of the cohorts ranged from 2 to 26 years (data not shown). The rs 7566605 polymorphism frequency was assessed in the different papers (graph 1). Furthermore, 38 parameters related to obesity were investigated, such as: biochemical parameters related to diabetes and hypertension, hematological, biochemical, renal, and hepatic parameters, behavior disturbances, anthropometrical measures and hormones (figure 2). From those, only 3 (BMI, WHR - Waist-Hip Ratio and HbArc - Glycated Haemoglobin) were associated with the presence of the polymorphism (figure 2). 
Table 1 - Details of the studies reviewed: sample information and study design

\begin{tabular}{|c|c|c|c|c|c|}
\hline SOURCE & COUNTRY & Study DESIGN & $\begin{array}{l}\text { SAMPLE } \\
\text { SIZE }\end{array}$ & $\begin{array}{l}\text { AGE RANGE (IN } \\
\text { YEARS) }\end{array}$ & BMI \\
\hline $\begin{array}{l}\text { Burgdörfer } \\
\text { et al., } 2013^{(20)}\end{array}$ & Germany & Case Control & 124 & 39.7 & $\mathrm{BMI} \cdot 4 \mathrm{O}$ \\
\hline $\begin{array}{c}\text { Kvaløy et al., } \\
2013^{(21)}\end{array}$ & Norway & Cohort & 1801 & $0-30$ & $\begin{array}{l}{ }^{* 2} 13-19 \text { years Men } 20.7 \text { (19.0- } \\
\text { 22.5) Women } 21.0 \text { (19.3-23.1) } \\
\text { 24-30 years Men 25.4 (23.2- } \\
\text { 28.6) Women } 24.1 \text { (21.9-27.6) }\end{array}$ \\
\hline $\begin{array}{l}\text { Malzahn } \\
\text { et al., 2014(22) }\end{array}$ & $\begin{array}{l}\text { Germany } \\
\text { and } \\
\text { USA }\end{array}$ & $\begin{array}{l}3 \text { Cohorts } \\
\text { KORA S3/F3 } \\
\text { KORA S4/F4 } \\
\text { FHS-Off }\end{array}$ & 6926 & $25-74$ & $\mathrm{BMI} \cdot 30$ \\
\hline $\begin{array}{l}\text { Angeli et al., } \\
2 \mathrm{Ol1}^{(30)}\end{array}$ & Brazil & Cross-sectional & 331 & $<17$ years & $\mathrm{BMI} \cdot 25$ \\
\hline $\begin{array}{l}\text { Gaifen et al., } \\
2011^{(31)}\end{array}$ & Georgia & $\begin{array}{l}2 \text { Cohorts } \\
\text { Georgia CV } \\
\text { Twin study } \\
\text { BP Stress study }\end{array}$ & 1592 & $\begin{array}{c}10-25.8 \\
\text { (Euroamerican) } \\
\text { 4.O-23.9 } \\
\text { (Afroamerican) }\end{array}$ & $\begin{array}{c}\text { Georgia CV } \\
\text { Twin study Men } 21.2 \pm 5.1 \\
\text { Women } 21.3 \pm 4.6 \\
\text { BP Stress Study } \\
\text { Men } 19.9 \pm 4.8 \\
\text { Women } 19.9 \pm 5.4\end{array}$ \\
\hline $\begin{array}{l}\text { Apalasamy } \\
\text { et al., 2014(32) }\end{array}$ & Malaysia & Case Control & 672 & $\begin{array}{c}\text { Non obese } \\
46.47 \pm 7.06 \\
\text { Obese } \\
47.97 \pm 6.05\end{array}$ & $\mathrm{BMI} \cdot 3 \mathrm{O}$ \\
\hline $\begin{array}{l}\text { Barth et al., } \\
2012^{(34)}\end{array}$ & Germany & Case control & 68 & $23-69$ & $\mathrm{BMI} \cdot 30$ \\
\hline $\begin{array}{c}\text { Baylin et al., } \\
2013^{(35)}\end{array}$ & $\begin{array}{l}\text { American } \\
\text { Samoa and } \\
\text { Samoa }\end{array}$ & Cohort & 717 & $22-55$ & $\begin{array}{c}\text { Samoa Men } 29.2(5.0) \\
\text { Women } 31.1 \text { (5.1) } \\
\text { American Samoa Men } 33.9 \\
\text { (6.0) Women } 35.9 \text { (7.1) }\end{array}$ \\
\hline $\begin{array}{l}\text { Manish et al., } \\
2013^{(36)}\end{array}$ & USA & Cohort & 1276 & $\begin{array}{l}41.8 \text { (Hispanics) } \\
46.1 \text { (American*) }\end{array}$ & $\begin{array}{c}\text { American*. } 50.2 \pm 8.8 \\
\text { Hispanics } 44.7 \pm 6.4\end{array}$ \\
\hline
\end{tabular}

Notes: USA - United States of American ${ }^{*}$ Information provided by the autor by e-mail*2Information from the supplementary informations from article.

Together, all the studies included a total of 16,617 patients from different areas, who were genotyped for the rs7566605 polymorphism (graph 1). The study of the allele frequencies shows a higher frequency of the GG genotype (higher than 50\%) in African descendents (Quilombo people and African-American), while the lowest frequencies were identified among Malays (32-33\%). On the other hand, for CC genotype, the lowest frequencies were found among African descendents and Hispanics (3-8\%), while the highest were reported among Malays and American Samoan women (15-21\%). The "German, European-American and Norwegian" groups showed similar frequencies (approx. 11.5\%) for the CC genotype. The highest frequency of the GC genotype was reported among 
Malays/Samoas (46-51\%) and the lowest among African descendents (22-39,5\%).

\section{DISCUSSION}

This systematic review attempted to understand the association between the rs75666o5 polymorphism with phenotype parameters and its frequencies among populations from several geographical areas. Nine papers were found, reporting and comparing the frequencies of genotypes from different populations. Three papers showed an association with some phenotypic parameter, especially BMI, WHR, and Hbarc. ${ }^{(20-22)}$

Although several phenotype traits were investigated, BMI was the single parameter assessed in all studies. However, only one study ${ }^{(22)}$ reported an association between the $\mathrm{rs} 7566605$ polymorphism with an increase in BMI. This could be explained by the method used by these authors, who investigated this polymorphism in a gene interaction process with the polymorphism rs2229616 from the $\mathrm{MC}_{4} \mathrm{R}$ gene, unlike other authors who analyzed the polymorphism rs7566605 individually.

Controversial findings were found for the WHR. One study(21) identified a positive association between the $\mathrm{C}$ allele with WHR in Norwegian adolescent males ( 13 to 19 years old) and adults (24 to 30 years old). On the other hand, another study ${ }^{(20)}$ demonstrated that the presence of the CC genotype from the rs7566605 polymorphism was associated with a lower WHR in Germans aged on average 39.7 years. Furthermore, no association was found among Quilombo people older than 17,(30) as well as among European-American and African-Americans aged between 15 and 26 years. ${ }^{(31)}$ These controversial findings may arise from the ethnic differences between the studied populations. Another study (37) suggests that WHR measure changes according to the population studied without, however, reflecting a direct association with the amount of body fat.

The HbArc rates were assessed only by. one study, ${ }^{(20)}$ who found an association between the CC genotype with lower levels of HbAic. The lack of further investigation involving this character and the polymorphism makes comparison with other papers very difficult. The pattern of genotype frequency of the rs7566605 polymorphism presented in all studies is corroborated by the literature. Similar frequencies among population groups from nearby geographical areas or with possible similar ancestry were also reported by the International Project HapMap ${ }^{(38)}$ which aimed to catalog the genotype profile in different populations worldwide. These findings were also corroborated by other study(40) reporting specific genetic variations among populations with a common ancestry and among those who live in nearby geographical areas.

Another highlighting result was the difference between the genotype frequency for men and women reported among Samoan and AmericanSamoan populations. This difference was not expected because the INSIG-2 gene is located on an autosomal chromosome, ${ }^{(41)}$ with no expected difference for gene segregation regardless of the gender. Furthermore, it is worth emphasizing that this reported difference can arise by chance, and it is not necessarily statistically significant, mainly because of the small sample size in the mentioned study. This limitation was recognized by the author herself. (35)

The genotype frequency for the African descendents compiled in this paper are similar to the genotypic frequency analyzed in Africans in the Hapmap Project. ${ }^{(39)}$ It is possible that the differences among the genotype frequencies on different populations may be explained by evolutionary aspects related to natural selection, as shown in a recent literature review, ${ }^{(42)}$ which demonstrated several genes possibly related to the process of natural selection.

\section{STRENGTHS AND LIMITATIONS OF THE REVIEW}

There are some limitations regarding the results reported in this study which should be taken into account. This is not a population study, consequently, this work is not affordable to determine the real genotype frequency of populations from different geographical areas. In addition, this review was limited to papers in English indexed in Pubmed. 
Furthermore, there is a lack of studies including representative populations from other areas, such as South America, Africa, Asia and Oceania. The reviewed papers contained important limitations, such as small sample size, selection bias, lack of control for important confounders such as age, participants' diet, use of medicines, genetic ancestry, as well as possible measurement error in the anthropometric variables. The papers also showed great variability in the age groups and reported variables, making comparison difficult.

Despite these limitations, this paper is the first attempt to compare the results from different studies, combining the genotype frequency from different populations. An understanding of the mutation distribution of genes potentially related to the obesity pandemic may improve the scientific knowledge about this phenomenon. It could also lead to new strategies for the investigation of genetic factors in the etiology of obesity, a multifactorial disease. Available preventive strategies have been unable to reduce its increase.

\section{CONCLUSION}

Despite the conflicting results among the investigated studies, this review shows an association among the rs7566605 polymorphism with three main traits: BMI, WHR, HbArc. The assessment of genotype frequencies showed specific patterns among populations belonging to similar geographical areas and/or ancestry. To our knowledge, this is the first review of the genotype frequency of the rs7566605 polymorphism in different populations and its association with obesity markers. The results of this work demonstrate the need for more research on the genotype frequency distribution, as well as possible associations with phenotype markers related to obesity.

FUNDING: This work was funded by Fapesb (Fundação de Amparo à Pesquisa do Estado da Bahia), through the program of scholarships.

\section{REFERENCES}

1. World Health Organization. Obesidad y sobrepeso. [Internet]. Fact sheet $\mathrm{N}^{\circ} 311$. [cited 2015 jan.]. Avaliable from: http://www.who.int/ mediacentre/factsheets/fs311/en/index.html

2. Hubert HB, Feinleib M, McNamara PM, Castelli WP. Obesity as an independent risk factor for cardiovascular disease: a 26-year follow-up of participants in the Framingham Heart Study. Circulation. 1983;67(5):968-77.

3. Ford ES, Williamson DF, Liu S. Weight change and diabetes incidence: findings from a national cohort of US adults. Am J Epidemiol. 1997;146(3):214-22.

4. Resnick HE, Valsania P, Halter JB, Lin X. Relation of weight gain and weight loss on subsequent diabetes risk in overweight adults. J Epidemiol Community Health. 2000;54(8):596-602.

5. Wilborn C, Beckham J, Campbell B, Harvey T, Galbreath M, La Bounty P, et al. Obesity: prevalence, theories, medical consequences, management, and research directions. J Int Soc Sports Nutr. 2005;2:4-31.

6. von Ruesten A, Steffen A, Floegel A, van der AD, Masala G, Tjonneland A, et al. Trend in obesity prevalence in European adult cohort populations during follow-up since 1996 and their predictions to 2015. PLoS One. 2011;6(11):e27455.

7. Ogden CL, Carroll MD, Kit BK, Flegal KM. Prevalence of obesity and trends in body mass index among US children and adolescents, 19992O1O. Jama. 2O12;307(5):483-9O.

8. Sorensen TI, Price RA, Stunkard AJ, Schulsinger F. Genetics of obesity in adult adoptees and their biological siblings. BMJ. 1989;298(6666):87-90.

9. Stunkard AJ, Harris JR, Pedersen NL, McClearn GE. The body-mass index of twins who have been reared apart. N Engl J Med. 1990;322(21):1483-7.

10. Paracchini V, Pedotti P, Taioli E. Genetics of leptin and obesity: a HuGE review. Am J Epidemiol. 2005;162(2):101-14.

11. Herbert A, Gerry NP, McQueen MB, Heid IM, Pfeufer A, Illig T, et al. A common genetic variant is associated with adult and childhood obesity. Science. 2006;312(5771):279-83. 
12. Rankinen T, Zuberi A, Chagnon YC, Weisnagel SJ, Argyropoulos G, Walts B, et al. The human obesity gene map: the 2005 update. Obesity (Silver Spring). 2006;14(4):529-644.

13. Mattevi VS, Zembrzuski VM, Hutz MH. Effects of a PPARG gene variant on obesity characteristics in Brazil. Braz J Med Biol Res. 2007;4O(7):927-32.

14. Heid IM, Huth C, Loos RJ, Kronenberg F, Adamkova V, Anand SS, et al. Meta-analysis of the NINSIG2 association with obesity including 74,345 individuals: does heterogeneity of estimates relate to study design? PLoS Genet. 2009;5(10):e1000694.

15. Data base Short Genetic Variations[Internet]: NCBI[Internet] 2010 Mar. [cited 2016 Mar O7]; 467: 52-58. Avaliable from: https://www.ncbi.nlm. nih.gov/projects/SNP/snp_ref.cgi?rs=7566605

16. Yabe D, Brown MS, Goldstein JL. Insig-2, a second endoplasmic reticulum protein that binds SCAP and blocks export of sterol regulatory elementbinding proteins. Proc Natl Acad Sci USA. 2002;99(20):12753-8.

17. Ferre P, Foufelle F. SREBP-lc transcription factor and lipid homeostasis: clinical perspective. Horm Res. 2007;68(2):72-82.

18. Lyon HN, Emilsson V, Hinney A, Heid IM, Lasky-Su J, Zhu X, et al. The association of a SNP upstream of INSIG2 with body mass index is reproduced in several but not all cohorts. PLoS Genet. 2007;3(4):e61.

19. Hotta K, Nakamura M, Nakata Y, Matsuo T, Kamohara S, Kotani K, et al. INSIG2 gene rs7566605 polymorphism is associated with severe obesity in Japanese. J Hum Genet. 2008;53(9):857-62.

2O. Burgdorfer E, Korenkov M, Jonas D, Weise $D$, Haaf T, Zechner U, et al. FTO and INSIG2 Genotyping Combined with Metabolic and Anthropometric Phenotyping of Morbidly Obese Patients. Mol Syndromol. 2013;4(6):273-9.

21. Kvaloy K, Kulle B, Romundstad P, Holmen TL. Sexspecific effects of weight-affecting gene variants in a life course perspective -The HUNT Study, Norway. Int J Obes. 2013;37(9):1221-9.
22. Malzahn D, Muller-Nurasyid M, Heid IM, Wichmann HE, Bickeboller H. Controversial association results for INSIG2 on body mass index may be explained by interactions with age and with MC4R. Eur J Hum Genet. 2014;22(10):1217-24.

23. Hall DH, Rahman T, Avery PJ, Keavney B. INSIG-2 promoter polymorphism and obesity related phenotypes: association study in 1428 members of 248 families. BMC Med Genet. 2006;7:83.

24. Boes E, Kollerits B, Heid IM, Hunt SC, Pichler M, Paulweber B, et al. INSIG2 polymorphism is neither associated with $\mathrm{BMI}$ nor with phenotypes of lipoprotein metabolism. Obesity (Silver Spring). 2008;16(4):827-33.

25. Talbert ME, Langefeld CD, Ziegler JT, Haffner SM, Norris JM, Bowden DW. INSIG2 SNPs associated with obesity and glucose homeostasis traits in Hispanics: the IRAS Family Study. Obesity (Silver Spring). 2009;17(8):1554-62.

26. Bressler J, Fornage M, Hanis CL, Kao WH, Lewis CE, McPherson R, et al. The INSIG2 rs7566605 genetic variant does not play a major role in obesity in a sample of 24,722 individuals from four cohorts. BMC Med Genet. 2009;10:56.

27. Deka R, Xu L, Pal P, Toelupe PT, Laumoli TS, Xi H, et al. A tagging SNP in INSIG2 is associated with obesity-related phenotypes among Samoans. BMC Med Genet. 2009;10:143.

28. Wiedmann S, Neureuther K, Stark K, Reinhard W, Kallmunzer B, Baessler A, et al. Lack of association between a common polymorphism near the INSIG2 gene and BMI, myocardial infarction, and cardiovascular risk factors. Obesity (Silver Spring). 2009;17(7):1390-5.

29. Skelding KA, Gerhard GS, Vlachos H, Selzer F, Kelsey SF, Chu X, et al. Association of an INSIG2 obesity allele with cardiovascular phenotypes is gender and age dependent. BMC Cardiovasc Disord. 2010;10:46.

30. Angeli CB, Kimura L, Auricchio MT, Vicente JP, Mattevi VS, Zembrzuski VM, et al. Multilocus analyses of seven candidate genes suggest interacting pathways for obesity-related traits in Brazilian populations. Obesity (Silver Spring). 2011;19(6):1244-51. 
31. Liu G, Zhu H, Dong Y, Podolsky RH, Treiber FA, Snieder H. Influence of common variants in FTO and near INSIG2 and MC4R on growth curves for adiposity in African- and European-American youth. Eur J Epidemiol. 2011;26(6):463-73.

32. Apalasamy YD, Moy FM, Rampal S, Bulgiba A, Mohamed Z. Genetic associations of the INSIG2 rs7566605 polymorphism with obesity-related metabolic traits in Malaysian Malays. Genet Mol Res. 2014;13(3):4904-10.

33. Liberati A, Altman DG, Tetzlaff J, Mulrow C, Gotzsche PC, loannidis JP, et al. The PRISMA statement for reporting systematic reviews and meta-analyses of studies that evaluate health care interventions: explanation and elaboration. PLoS Med. 2009;6(7):e1000100.

34. Barth SW, Koch TC, Watzl B, Dietrich H, Will F, Bub A. Moderate effects of apple juice consumption on obesity-related markers in obese men: impact of diet-gene interaction on body fat content. Eur J Nutr. 2O12;51(7):841-5O.

35. Baylin A, Deka R, Tuitele J, Viali S, Weeks DE, McGarvey ST. INSIG2 variants, dietary patterns and metabolic risk in Samoa. Eur J Clin Nutr. 2013;67(1):101-7.

36. Parikh M, Hetherington J, Sheth S, Seiler J, Ostrer $\mathrm{H}$, Gerhard G, et al. Frequencies of obesity susceptibility alleles among ethnically and racially diverse bariatric patient populations. Surg Obes Relat Dis. 2013;9(3):436-41.

37. World Health Organization. Waist circumference and waist-hip ratio: report of a WHO expert consultation, Geneva, 8-11 December 2008 [Internet]. [cited $2016 \mathrm{Mar}$ O3]. Avaliable from: http://apps.who.int/iris/ bitstream/10665/44583/1/9789241501491_ eng.pdf

38. The International HapMap Consortium. The International HapMap Project. Nature [Internet]. 2003 Mar [cited 2016 Mar 1]; 426:789-796. Avaliable from: http://hapmap.ncbi.nlm.nih.gov/ cgiperl/snp_details_phase3?name=rs7566605\&so urce=hapmap28_B36\&tmpl=snp_details_phase3

39. European Molecular Biology Laboratory. Ensembl [Internet]. rs7566605. Avaliable from: http:// www.ensembl.org/Homo_sapiens/Variation/ Population?db=core;r=2:118077949-118078949; v= rs7566605; vdb=variation;vf=4369425" populati on_freq_AFR

4O. Jorde LB, Wooding SP. Genetic variation, classification and 'race'. Nat Genet. 2004;36(11):S28-33.

41. INSIG2 insulin induced gene 2 [Homo sapiens (human). [Internet] Gene. [cited 2016 Mar O3]. Avaliable from: http://www.ncbi.nlm.nih.gov/ gene/51141.

42. Sabeti PC, Schaffner SF, Fry B, Lohmueller J, Varilly P, Shamovsky O, et al. Positive natural selection in the human lineage. Science. 2006;312(5780):1614-20.

43. Strina A, Barreto ML, Cooper PJ, Rodrigues LR. Risk factors for non atopic asthma/wheeze in children and adolescents: a systematic review. Emerg Themes Epidemiol. 2014;11(5):1-11. 